\title{
PDX1 Gene
}

National Cancer Institute

\section{Source}

National Cancer Institute. PDX1 Gene. NCI Thesaurus. Code C118247.

This gene plays a role in the regulation of insulin and insulin-responsive genes. 